\author{
Case Report \\ www.ijrap.net
}

\title{
AYURVEDIC MANAGEMENT OF PAKSHAGHATA \\ (RIGHT MIDDLE CEREBRAL ARTERY HEMORRHAGIC INFARCT): A CASE REPORT
}

Vasan Satish ${ }^{1 *}$, M Ashvinikumar $^{2}$, BA Lohith ${ }^{3}$, Rajan Amritha ${ }^{4}$

${ }^{1}$ PG Scholar, Department of Panchakarma, SDM College of Ayurveda, Hassan, Karnataka, India

${ }^{2}$ Professor, Department of Panchakarma, SDM College of Ayurveda, Hassan, Karnataka, India

${ }^{3}$ Head and Associate Professor, Department of Panchakarma, SDM College of Ayurveda, Hassan, Karnataka, India

${ }^{4}$ Assistant professor, Department of Panchakarma, SDM College of Ayurveda, Hassan, Karnataka, India

Received on: 14/06/16 Revised on: 12/07/16 Accepted on: 02/08/16

\author{
*Corresponding author \\ E-mail: drsatish.vasan@gmail.com
}

DOI: 10.7897/2277-4343.074169

\begin{abstract}
Stroke is defined as the rapid onset of focal neurological deficit resulting from diseases of the cerebral vasculature and its contents. Stroke represents the third most common cause of death in developed nations. The prevalence of stroke in India is approximately 200 per 100,000 persons and $9.94 \%$ of total deaths. The present article deals with a diagnosed case of hemorrhagic stroke presenting with left sided hemiplegia with right Middle cerebral artery hemorrhagic infarct. The Ayurvedic diagnosis of Vama pakshaghata was made and managed with Parisheka (Pouring of medicated liquids), Shiropichu (Applying oil to vertex using cotton pad), Pradhamananasya (Administration of powdered medicine through nasal route), Shastika Shali Masha Pinda Sweda (Full body massage with bolus prepared by rice and black gram ) and Matrabasti (Administration of medicated ghee through rectum). Two assessments were made before and after treatment using the National Institute of Health Stroke Scale (NIH-SS) and Stroke Specific Quality of Life Scale (SS-QOL). Maximum improvement was noticed in the symptoms of facialpalsy, aphasia and dysarthria. There were also improvement in left lower and upper extremity functions. At the end of the treatment he could walk without support. Assessment using SS-QOL showed considerable recovery in language ability, mobility, energy, mood, self-care and vision. Panchakarma plays a key role in the management of stroke/Pakshaghata. The recovery was promising and worth documenting.
\end{abstract}

Keywords: Ayurveda, Pakshaghata, Panchakarma, Stroke, Hemiplegia, MCA Syndrome

\section{INTRODUCTION}

The term Pakshaghata literally means "paralysis of one half of the body" where "paksha" denotes either half of the body and "Aghata (=paralysis)" denotes the impairment of Karmendriyas, Gyanendriyas and Manas.

Gyanendriyas are considered a part of the sensory system and Karmendriyas are considered a part of the motor system. The Manas is supposed to control and guide both, Gyanendriyas and Karmendriyas. Pakshaghata is a Vatavyadhi of Nanatmaja variety. ${ }^{1}$ Mahavatavyadhi can manifest either due to Dhatukshaya or margavarana. ${ }^{2}$ The cardinal features of Pakshaghata include Chestahani (impaired motor activity), Ruja (pain), Vakstambha (slurring of speech), and Hasta Pada Samkocha. ${ }^{3}$ Sandhi Bandhavimoksha (weakness of joints) Vaktravakratha (mouth deviation), Sphoorana of Jihva (fasciculation of the tongue) may also be associated in some cases. Pakshaghata can be correlated with hemiplegia. Hemiplegia is a disease with paralysis of one side of the body. The term "hemiplegia" (Root: "hemi"+ "plege"= "half" +"blow"). Stroke is defined as rapid onset of focal neurological deficit resulting from diseases of the cerebral vasculature and its contents stroke represents third most common causeof death in developed nations. ${ }^{4}$ According to the latest WHO data published in May 2014 Stroke Deaths in India reached 881,702 or $9.94 \%$ of total deaths. ${ }^{5}$ The prevalence of stroke in India is approximately 200 per 100000 persons. $^{4}$ Stroke, sometimes referred to as a cerebro-vascular accident (CVA), or cerebrovascular insult $(\mathrm{CVI})$, is the loss of brain function due to a disturbance in the blood supply to the brain. This disturbance is due to either ischemia (lack of blood flow) or hemorrhage. The middle cerebral artery divides into the right middle cerebral artery and a left middle cerebral artery. The right middle cerebral artery provides blood to a large part of the right side of the brain. The artery divides into smaller artery branches. Based on where the blockage occurs in the artery or in the branches, the effects will vary. The clinical presentation of MCA occlusion is variable. Contra lateral hemiplegia, hemianesthesia with or without homonymous hemianopia and aphasia (dominant hemisphere) are common manifestations.Occlusion of the superior division presents as contralateral hemiparesis with sensory deficit and expressive aphasia (Broca's aphasia) whereas Wernicke's aphasia (sensory aphasia) is frequent in case of a lesion of the inferior division of the dominant side. ${ }^{6}$

Panchakarma is one of the important treatment modality of Ayurveda. Panchakarma literally means five procedures, vaman (therapeutic emesis), virechan (purgation), asthapanvasti (enema using medicated decoction), anuvasanvasti (enema using medicated oil) and shirovirechan /nasya (nasal administration of medicines). Along with this five major procedures there are various other allied therapies like snehan (oleation), swedan (fomentation) etc; are also collectively comes under panchakarma. Panchakarma has no adverse effects and it is very useful in treating neurological diseases as well as paralysis. ${ }^{7}$ By considering all the above facts the present study was planned to assess the efficacy of stroke with panchakarma therapy. 


\section{CASE DESCRIPTION}

A 64 years old male came to our hospital (12\3\16) with complaints of weakness of the left side of his body including face and inability to walk since 30 days. The subject was a previously diagnosed case of Cerebro-vascular Accident (Right Middle Cerebral Artery Hemorrhagic Infarct).

\section{HISTORY}

On 12/5/15 the subject observed a sudden dribbling of water from his mouth, when drinking water, followed by slight deviation of the angle of the mouth, associated with slurred speech, weakness of the left upper and lower limbs and inability to stand and walk. He was admitted at an allopathic hospital and was diagnosed as a case of CVA for which he treated. He didn't get satisfactory relief. From $1 / 6 / 15$ to $15 / 6 / 15$ he underwent Ayurvedic treatment for the same and was discharged after remarkable improvement.

On16/2/16 the subject had one episode of convulsion lasting for 5 minutes associated with tongue bite. He was taken to the nearest allopathic hospital but his condition worsened. He was bedridden gradually, unable to move the left half of his body which was associated with semi consciousness. He sought Ayurvedic care with us on 12/3/16 to regain normal functions of both the limbs of left side and speech.On the day of admission, the subject was in semiconscious state, drowsy, responding only to deep stimulation and not responding to oral commands. His blood pressure was 140/80mm of Hg, Temperature 99 Degree Fahrenheit, with only flickering movements observed in the left limbs (Power 1/5) and unaffected right limbs (power 5/5). The subject had an associated complaint of skin lesion (herpes zoster) in right lumbar region (T7, T8) and constipation since 7 days. The subject is a known case of Diabetes Mellitus II since 8 years and had LV Diastolic Dysfunction. Hematological and biochemical investigation reports were within normal limits. No past history of head injury, hypertension, or dyslipidemia could be elicited.

\section{Diagnosis}

Cerebro - vascular accident was diagnosed by history and clinical examination.

\section{CT HEAD shows $(14 / 5 / 15)$}

- Ill-defined hypo densities involving the right fronto temporal and parieto- occipital region with loss of grey white matter differentiation s/o acute infarct.

- Chronic infarcts involving bilateral occipital region.

\section{MRI BRAIN shows (16/5/15)}

- Altered signal intensity involving the right parietal frontal and occipital region appearing hypo intense on $\mathrm{T} 1 \mathrm{w}$, hyperintense on T2w, FLAIR sequence and showing diffuse restriction with corresponding hypo intense signal on ADC multiple areas of blooming on GRE sequence s/o hemorrhagic infarct in right MCA territory .

- Altered signal intensity in the left posterior parietal and occipital region appearing hypo intense on T1w hyper intense on T2w FLAIR sequences but not showing diffuse restriction s/o chronic infarct

EEG showed abnormal graph showing evidence of neural hyper excitation - low amplitude wave forms seen in all the leads bilaterally.

Subject was diagnosed with Pakshaghata (Vamaparshwa) and Visarpa according to Ayurveda.

\section{TREATMENT}

Initially, Parisheka with Panchavalkala Kashaya and Dashangalepa for local application was done, followed by Shiropichu, Pradhamananasya, and Matrabasti. The subject was discharged (30/4/2016) and internal medicines were prescribed for the period of one month (Table 1)

Table 1: Intervention

\begin{tabular}{|l|l|}
\hline \multicolumn{1}{|c|}{ Panchakarma intervention } \\
\hline $12 / 03 / 16$ to $20 / 03 / 2016$ & Sarvanga Parisheka with Panchavalkala Kashaya \\
\hline $12 / 03 / 16$ to $30 / 04 / 2016$ & Shiropichu with Bramhi Ghritha \\
\hline $19 / 03 / 16$ to $30 / 04 / 2016$ & Pradhamana Nasya withVacha choorna and Swasakutara rasa \\
\hline $19 / 03 / 16$ to $30 / 04 / 2016$ & Matrabasti with Bramhi Ghritha 40ml \\
\hline $19 / 03 / 16$ to $30 / 04 / 2016$ & Sarvanga Abyanga with Mahamasha Taila \\
\hline $01 / 04 / 16$ to $30 / 04 / 2016$ & Sarvanga Abyanga with Mahamasha Taila and Shastika Shali Masha Pinda Sweda \\
\hline $01 / 04 / 16$ to $30 / 04 / 2016$ & Pratimarsha Nasya with Bramhi Ghritha four drops each nostrils at evening \\
\hline Medicines prescribed at the time of discharge \\
\hline \multirow{3}{*}{$30 / 04 / 16$ to $30 / 05 / 16$} & Pratimarsha Nasya with Bramhi ghritha two drops. BD \\
\cline { 2 - 2 } & Kalyanaka Ghritha one tea spoon \\
\cline { 2 - 2 } & Shiropichu with Kalyanaka Ghritha \\
\cline { 2 - 2 } & Tablet- Kamaduga with Muktha two BD \\
\hline
\end{tabular}

\section{DISCUSSION}

The subject was taking anticonvulsants prior to the Ayurvedic treatment, which was gradually tapered off during the course of the treatment. The subject is of poor built, having Avarabala (Poor strength), Avarasatva (Poor mental strength), and Avara Jeerna Shakti (Reduced digestion power). Hence, Shodhana line of treatment was not followed. Saama Vata lakshana's like, Vibandha (constipation), Agnisaada (Poor digestive capacity) and Aantrakujana (borborygmi) were seen. $8^{8}$ He was also suffering from Visarpa (T7, T8). Based on these features, treatment aiming at Amapachana and Pittashamana was given. Initially Sarvanga parisheka with Panchavalkala kashaya was given. Panchavalkala kashaya has Ruksha, Kapha Pitta Shothahara, Shitaguna and has wound healing property. ${ }^{9}$ For local application on Visarpa, Dashanga Lepa was given. Bramhi Ghritha Shiro Pichu is also Vata Pitta Hara. It improves memory,speech, intelligence, and gives strength to the head and sense organs. ${ }^{10}$ Pradhamana Nasya with Vacha Choorna and Shwasa kuthara Rasa was done to restore consciousness 
levels. ${ }^{11,12}$ When the symptoms of drowsiness and heaviness of body had reduced (when Nirama Avasta attained), there was increase in the digestion power and he began responding to oral commands. Later Bramhi Ghritha Matra Basti $40 \mathrm{ml}$ and Sarvanga Abyanga with Mahamasha Taila followed by Shastika Shali Masha Pinda Sweda was advised. This is a kind of sweda that makes the body supple, removes stiffness of joints vitiated by Vatadosha, cleanses the srotas of the body, improves blood circulation, removes sluggishness of the body and is also balya. ${ }^{13}$ Masha has Madhura Rasa, Snigdha Ushna Guna and is Balakara. ${ }^{14}$ Bramhi Ghritha Prathimarsha Nasya was advised in the evening to pacifyVatadosha. ${ }^{15}$ After a period of 45 days, the subject started walking with support initially, and then without support. Visarpa was also cured.

Table 2: Assessment scale

\begin{tabular}{|c|c|c|c|c|}
\hline S.no & NIH Scale & Range of score & Before treatment Score & After treatment score \\
\hline $1 \mathrm{a}$. & Level of Consciousness & 0 to 3 & 2 & 0 \\
\hline $1 \mathrm{~b}$. & LOC Questions & 0 to 2 & 2 & 0 \\
\hline $1 \mathrm{c}$. & LOC Commands & 0 to 2 & 1 & 0 \\
\hline 2 & Best Gaze & 0 to 2 & 0 & 1 \\
\hline 3 & Visual & 0 to 3 & 1 & 0 \\
\hline 4 & Facial Palsy & 0 to 3 & 3 & 0 \\
\hline 5 & Motor Arm & 0 to 4 & 3 & 0 \\
\hline 6 & Motor Leg & 0 to 4 & 0 & 0 \\
\hline 7 & Limb Ataxia & 0 to 2 & 1 & 0 \\
\hline 8 & Sensory & 0 to 2 & 2 & 1 \\
\hline 9 & Best Language & 0 to 3 & $\mathbf{1 8}$ & 1 \\
\hline 10 & Dysarthria & 0 to 2 & $\mathbf{4 2}$ & \\
\hline
\end{tabular}

Maximum score is 42, signifying severe stroke; Minimum score is 0, a normal exam; Scores greater than 15-20 are more severe.

\section{CONCLUSION}

This case study demonstrates the successful management of a case of Pakshaghata (Middle Cerebral Artery infarct) using Ayurvedic treatment. While the scope for further research and clinical trials is enormous, it remains substantiated, that with proper diagnosis and selection of treatment protocol, Ayurveda can be enormously beneficial in the treatment of stroke, or Pakshaghata. Pradhamana Nasya with Vacha Choorna and Shwasa Kuthara Rasa were found to be extremely helpful in Sanjna prabodhana of the subject. These, along with Pancha Valkala Kashaya Parisheka brought about Niramavastha in the subject. Brahmi Ghritha Matrabasti, along with Maha Masha Taila Abhyanga followed by Shashtika Shali Masha Pinda Sweda was given to pacify Vata, increase strength and restore motor as well as sensory functions. It is said that the ideal drug, is one which can cure multiple diseases and presentations of disease. In this case, Panchavalkala Kashaya Parisheka not only caused Amapachana of the body, but also helped in wound healing in Visarpa due to its Ruksha, Pittashamaka, and Vranaropaka properties. Due to the uncommon nature of the presentation, and complete recovery over the span of 45 days, this case was thought worth documenting.

\section{REFERENCES}

1. Agnivesha, Charaka, Dridabala. Charaka Samhith, Sutrastana, Maharoga Adyaya, Chapter20, Verse11, Edited by Vaidya Yadavaji Trivikramaji Acharya. Chaukambha Prakashana, Varanasi 2013;P113

2. Agnivesha, Charaka, Dridabala. Charaka Samhith, ChikistaStana Vatavyadi Chikistitam Adyaya, Chapter 28, Verse59. Edited by Vaidya Yadavaji Trivikramaji Acharya. Chaukambha Prakashana, Varanasi 2013;P 619

3. Agnivesha, Charaka, Dridabala. Charaka Samhith, ChikistaStana, Vatavyadi Chikistitam Adyaya, Chapter28, Verse53-55. Edited by Vaidya Yadavaji Trivikramaji Acharya. Chaukambha Prakashana, Varanasi 2013;P 619
4. Munjal YP API Text book of medicine. Vol-2, $9^{\text {th }}$ edition. New Delhi. Jaypee brothers Medical publishers(p) Ltd. 2012; P- 1401

5. World Health Rankings - The top 20 Causes of Death in India. http://www.worldlifeexpectancy.com/india-stroke. Published By WHO May 2014. Accessed on $6^{\text {th }}$ June, 2016. $1.47 \mathrm{pm}$

6. Munjal YP API Text book of medicine. $9^{\text {th }}$ edition.Vol-2, Newdelhi. Jaypee brothers Medical publishers (p) Ltd. 2012; P 1403.

7. Prasad Mamidi, Kshama Guptha. Role of stroke unit care with panchakarma in the management of stroke: An observational case series. Int. J. Res. Ayurveda Pharma. 2014;5(3):252-255 http://dx.doi.org/10.7897/22774343.05351

8. Vagbhatacharya, Astanga Hrudaya, Sutrastana, Doshopakramaniya adyaya. Chapter13, Verse23, Edited by Dr Anna Moreshvara Kunte and Dr Krishna shastrynavare, Choukhamba Samskruta Samsthana, Varanasi 2010;P 216

9. Bhava Mishra, Bhavaprakasha Samhitha, Vatadivarga. Edited by Bramha Shankara Mishra, Choukhamba Samskruta Samsthana, Varanasi;P 516

10. Vagbhatacharya ,Astanga Hrudaya, Uttarastana , Unmada Pratishedaniya adyaya. Chapter6, Verse23-26, Edited by Dr Anna Moreshvara Kunte and Dr Krishna shastrynavare, Choukhamba Samskruta Samsthana, Varanasi 2010;P 799

11. Acharya Sharangadhara. Sharangadhara Samhitha. Uttarakanda,Chapter 8,Verse22, Edited by Brahmanand tripathi. Choukamba surabharati prakashanaVaranasi; 2004;P 375

12. Acharya bhavamishra. Bhavaprakasha Samhitha. Vol II,Madyamakanda, shwasarogadhikara, Chapter14, Verse51. Edited by Pandit Sri Brahma Sankara Misra. Choukamba Sanskrit Bhawana; 2013; P166

13. Patil Vasant C. Principles And Practice of Panchakarma. $1^{\text {st }}$ Edition, Chaukhambha publications New Delhi; P 206-210.

14. Vagbhatacharya ,Astanga Hrudaya, Sutrastana Annaswaroora Vignaniyaadyaya. Chapter6, Verse21, Edited by Dr Anna Moreshvara Kunte and Dr Krishna 
shastrynavare, Choukhamba Samskruta Samsthana, Cite this article as:

Varanasi $2010 ; \mathrm{P} 88$

15. Vagbhatacharya , Astanga Hrudaya, Sutrastana Nasyavidiadyaya.Chapter20,Verse13-14, Edited by Dr Anna Moreshvara Kunte and Dr Krishna shastrynavare, Choukhamba Samskruta Samsthana, Varanasi2010;P 290
Vasan Satish, M Ashvinikumar, BA Lohith, Rajan Amritha. Ayurvedic management of Pakshaghata (right middle cerebral artery hemorrhagic infarct): A case report. Int. J. Res. Ayurveda Pharm. Jul - Aug 2016;7(Suppl 3):126-129 http://dx.doi.org/ $10.7897 / 2277-4343.074169$

Source of support: Nil, Conflict of interest: None Declared

Disclaimer: IJRAP is solely owned by Moksha Publishing House - A non-profit publishing house, dedicated to publish quality research, while every effort has been taken to verify the accuracy of the content published in our Journal. IJRAP cannot accept any responsibility or liability for the site content and articles published. The views expressed in articles by our contributing authors are not necessarily those of IJRAP editor or editorial board members. 